\title{
Alternatif Turizme Yönelik Bibliyometrik Bir Araştırma
}

\author{
A Bibliometric Research on Alternative Tourism \\ Ebru DÜŞMEZKALENDER* \\ Merve METIN**
}

$\ddot{O} Z$

Bu çalışmada, alternatif turizm başlıklı makalelerin bazı bibliyometrik özellikler açısından incelenmesi amaçlanmaktadır. Bu doğrultuda 2000-2018 yılları arasında yayımlanan makaleler değerlendirmeye alınmıştır. Makalelere erişim için Yükseköğretim Akademik (YÖK Akademik) Arama veri tabanı kullanılmış, alternatif turizm anahtar kelimeleriyle tarama yapılmış ve neticede ulaşılabilen 60 makale değerlendirmeye alınmıştır. Makaleler yayımlandı̆̆ yıl, yayımlandığı dergi, yazar sayısı, kaynakça sayısı, anahtar kelime sayısı, araştırma türü, içeriği, yazarların çalıştıkları kurumlar gibi kriterler temelinde incelenmiştir. Bu değerlendirme sonucunda, alternatif turizm ile ilgili en fazla makalenin 2017 yllında yayımlandı̆̆ ve makalelerde iki yazarlılı̆̆ın fazla olduğu görülmektedir. Konu ile ilgili en fazla makale Atatürk Üniversitesi Sosyal Bilimler Enstitüsü Dergisi’nde yayımlanmıştır. Çalışmaya ait diğer bulgular, son yıllarda alternatif turizm ile ilgili çalışma sayısının giderek arttı̆̆ını göstermektedir.

ANAHTAR KELIMELER

Alternatif Turizm, Turizm, Bibliyometrik Analiz

\begin{abstract}
In this study, it is aimed to investigate some bibliometric properties of the articles with the title of alternative tourism. In this context, the articles published between 2000-2018 were evaluated. For access to the articles, Higher Education Academic (YOK Academic) Search database was used, and 60 articles which were obtained through the keywords of alternative tourism were taken into consideration. The articles were examined based on some criteria such as the year of publishing, the journals where articles are published, the number of authors, the number of references, the number of keywords, the research method, the content, the institutions where the authors work. As a result of this evaluation, it was seen that most articles on alternative tourism were published in 2017 and most of the papers were written by two authors. The Journal of the Institute of Social Sciences of Atatürk University was found to be the journal where most articles were published. The other findings of the study reveal that the number of studies on alternative tourism has been increasing in recent years.
\end{abstract}

\section{KEYWORDS}

Alternative Tourism, Tourism, Bibliometric Analysis

\begin{tabular}{|c|c|c|}
\hline \multicolumn{2}{|r|}{$\begin{array}{c}\text { Makale Geliş Tarihi / Submission Date } \\
\text { 28.03.2019 }\end{array}$} & $\begin{array}{c}\text { Makale Kabul Tarihi / Date of Acceptance } \\
11.11 .2019\end{array}$ \\
\hline Atıf & $\begin{array}{l}\text { Düşmezkalender, E. ve Metin, M. } \\
\text { Üniversitesi Sosval Bilimler Meslek Yi }\end{array}$ & $\begin{array}{l}\text { izme Yönelik Bibliyometrik Bir Araştırma. Selçuk } \\
\text { 2), 813-824. }\end{array}$ \\
\hline
\end{tabular}

\footnotetext{
* Dr. Öğr. Üyesi, Eskişehir Osmangazi Üniversitesi, Turizm Fakültesi, Turizm İşletmeciliği Bölümü, earslaner@ ogu.edu.tr, ORCID: 0000-0001-6197-1394

** Yüksek Lisans Öğrencisi, Eskişehir Osmangazi Üniversitesi, Sosyal Bilimler Enstitüsü, Turizm İşletmeciliği Bölümü, mervemetin9@ gmail.com, ORCID: 0000-0002-2754-8151
} 


\section{GİRIŞ}

Turist beklentilerinin zamanla değişiklik göstermesi, gürültüden ve kent yaşamından uzaklaşma isteği, daha doğal bir yaşam ve daha kaliteli hizmet beklentisi turistler için farklı arayışları gündeme getirmiştir. Bu arayışlar neticesinde alternatif turizm kavramı belirmiş; süregelen tatil anlayışı değişmiş ve daha farklı ve yeni turizm çeşitleri ortaya çıkmıştır (Ulusan ve Batman, 2010:243). Bununla birlikte kitle turizminin yarattığ1 hayal kırıklığı ve tetiklediği birçok problem alternatif turizme dönük yöntemler geliştirilmesini hızlandırmıştır (Brohman, 1996:63). Turistler, yerel halk ve diğer turizm paydaşlarının kitle turizminin olumsuz etkileri konusundaki artan farkındalığı da alternatif turizmin ortaya çıkmasını güçlendiren nedenlerdendir (Jovicic, 2016:608-609). Dolayısıyla bütün bu bilgilerden hareketle, alternatif turizmin doğuşunun kitle turizmine yönelik eleştirilere ve destinasyonlarda yarattığı olumsuz etkilere bağlandığı ifade edilebilir (Christou, 2012). Sürdürülebilirliği esas alarak; çevreye, doğaya ve kültürel kaynaklara duyarlı bir anlayışı benimseyen alternatif turizm türlerinin gelişme göstermesi, akademik yazına da yansımış; alternatif turizm konusunu ele alan birçok makale yazılmış ve bilimsel dergilerde yayımlanmıştır. Bilimsel yayınların belirli kriterler dâhilinde sınıflandırılması ve değerlendirilmesi hususunda sıklıkla tercih edilen tekniklerden birisi de bibliyometrik analizlerdir. Bibliyometrik araştırmalarda belgelerin ya da yayınların belirli nitelikleri değerlendirilip, çözümlenerek bilimsel bulgular elde edilmektedir (Ulu ve Akdağ, 2015:6). Daha açık anlatımla, bibliyometrik çalışmalarla yazar, konu, atıf, kaynaklar ile ilgili istatistiksel veri toplanması; bu istatistiksel veriler 1şığında da belli bir alana yönelik genel bir durum değerlendirmesi yapılabilmektedir (Çetinkaya Bozkurt ve Çetin, 2016:232).

$\mathrm{Bu}$ çalışmada YÖK Akademik veri tabanında yayımlanmış olan alternatif turizm başlıklı makalelerin bibliyometrik bir yaklaşımla değerlendirilmesi amaçlanmaktadır. Bu kapsamda çalışmanın bir bölümünde ilgili literatüre, diğer bölümünde ise bibliyometrik analize ilişkin bulgulara yer verilmiştir. Bibliyometri geçmişte yapılan birçok çalışmanın tek bir çalışmada özetlenmesi anlamında dikkat çekici bir özelliğe sahiptir. Ayrıca bibliyometrik yaklaşımın nesnelliği, alanın durumunu daha titiz bir değerlendirmeye tabi tutması anlamında önemlidir (Ruhanen ve diğ., 2015:15-16). Alternatif turizmin gelişme göstermesi ve yapılan çalışmaların sayıca artması; bu çalışmaların sentezlenmesi ve tek bir çalışmada sınıflandırılmış bir görüntü sunmasını gerekli kılmaktadır. Bu durum alanın genel değerlendirilmesi açısından önem arz etmektedir. Ancak literatür incelendiğinde alternatif turizm alanında yapılmış bir bibliyometri çalışması olmadığı görülmektedir. $\mathrm{Bu}$ çalışmada alternatif turizm literatürünün özellikleri nelerdir sorusuna cevap aranmaktadır. Turizmin farklı alt konu başlıkları ile ilgili yapılacak olan bibliyometri çalışmalarının alana ilişkin kapsamlı bir bakış açısı sunarak katkı sağlayabileceği (Özel ve Kozak, 2012:717) düşüncesinden hareketle de, bu çalışmanın literatüre katkı sağlayacağı ve yapılacak bundan sonraki çalışmalar için yol gösterici nitelikte olacağı düşünülmektedir.

\section{LITERATÜR}

\subsection{Alternatif turizm}

Kitle turizmine yönelmiş az gelişmiş ya da gelişmekte olan ülkelerde kaynak kullanımı fazla ve dengesizdir. Kitle turizmi yapılan bölgelerde doğal, kültürel ve tarihi değerler daha fazla tahrip edilmekte, çevresel ve kültürel kirlilik ortaya çıkmaktadır (Akoğlan Kozak ve Bahçe, 2009:115-116). Daha açık ifadeyle, kitle turizminin gelişimi, yoğunlaştığı kıyı bölgelerinde yerel mimariyle uyuşmayan yapıların yaygınlaşmasına ve aşırı yapılaşmaya neden olarak, bu bölgelerde özgün dokunun bozulmasına kıyı, hava ve gürültü kirliliğine, yeşil alanların, tarihi ve arkeolojik mekanların tahrip olmasına (Roney, 2011:20) ve bazı sosyal sorunların ortaya çıkmasına (Zengin ve Sancar, 2014:141) neden olmaktadır. Bu sorunlara bağlı olarak, 1970'ler ve 1980 'lerin başında gelişmekte olan ülkelerde geleneksel turizm, kitle turizmi ya da istenmeyen turizm olarak ifade edilen turizm türleri için alternatif bir çözüm olarak yeni turizm türleri ortaya çıkmıştır (Triarchi ve Karamanis, 2017a:39). Kısa Ovalı'nın (2007:74) anlatımıyla da alternatif turizm arayışlarının temelinde, kitle turizmine yönelik olumsuz tepkiler ve çevreci örgütlerin toplumların kaynakların yok edilmemesi gerektiği hususunda yarattığı bilincin önemli rol oynadığı düşünülmektedir. Akoğlan Kozak ve diğ.'nin (2013) ifadeleriyle ise, post modern dönem olan 1980'lerden sonra yaşanan değişimler, bireyselliği, alternatif ürünleri, çevre hassasiyetini, zaman ve mekan kısıtından kurtulmayı önemli hale getirmiştir. Bu dönemde, farklılık beklentisi olan bireylerin kitle turizminden keyif almaması aynı zamanda kitle turizminin çevreye zarar verdiği düşüncesi yaygınlaşmış, farklı turistik ürünlere yönelim başlamıştır. Cohen (1987) de, çalışmasında alternatif turizmin çıkışını iki nedene bağlayarak bunları modern tüketime ve üçüncü dünyanın sömürülmesine bir tepki göstermekle bağlantılı olarak açıklamaktadır.

Alternatif turizm literatürü alternatif turizmin doğuş dönemini, Jafari'nin adaptasyon dönemi olarak göstermektedir. Araştırmacıya göre uyarıcı dönemde turizmin olumsuz etkileri incelenmiş ancak bu 
olumsuzlukların nasıl ortadan kaldırılacağı ve olumsuzluklara nasıl bir çözüm bulunacağı belirlenememiştir. Bu dönemde alternatif turizm olgusu kitle turizmine alternatif olarak antitez şeklinde sunulmuştur (Baytok ve diğ., 2017:3). Bu bağlamda geliştirilen tanımlarda alternatif turizm, arzu edilmeyen kitle turizminin karşıtı olarak; olumlu etkileri olan ya da çok az olumsuz etkisi olan ideal bir turizm formu olarak değerlendirilmektedir (Erdoğan, 2003). Bununla birlikte alternatif turizm bazı kaynaklarda kitle turizmini reddeden (Isaac, 2010:24) bazı kaynaklarda ise kitle turizmine alternatif olarak gelişen bir turizm türü (Kılıç ve Kurnaz, 2010:42) olarak betimlenmektedir.

Alternatif turizm; doğaya duyarlı ve sürdürülebilir ilkelere bağlı kalarak geliştirilmesi gereken turizm çeşitleri olarak tanımlanmaktadır (Baytok ve diğ., 2017:1). Akoğlan Kozak ve Bahçe'nin (2009:97) tanımıyla alternatif turizm, "kitle turizminin etkilerini azaltan ve turizm gelirlerini dengeli ve yerel halka öncelik verecek şekilde dağıtarak refah seviyelerinin yükselmesine katkıda bulunan, turizmden gelir akışını daha geniş zaman ve kesimlere yayan turistik ürün ve hizmetler içeren turizm çeşididir”. Alternatif turizm düşüncesi, gelecek kuşakların kullanma hakkından ödün vermeden günümüz turizm faaliyetlerinin planlanmasını ve yürütülmesini sağlayan ve bu çerçevede gelecekteki turizm gelişimlerine de yol gösterici bir çözüm modeli olarak ön plana çıkmaktadır (Duran ve Özkul, 2018:143). Diğer taraftan plansız, dengesiz gelişme ve yerel halk başta olmak üzere paydaşların turizmden sağladığı faydaların eşit dağılmaması alternatif turizmin ortaya çıkışına zemin hazırlayan önemli konular olarak görülmektedir (Baytok ve diğ., 2017:5). Turizme katılanların farklı bir deneyim yaşamak istemeleri, yeni şeyler keşfetmek ve yeni şeyler görmek istemeleri de alternatif turizmin önemini artırmıştır (Çeken ve diğ., 2012:11). Alternatif turizm türlerine olan ilgiyi artıran başka sebep, tüm y1la yayılması ve farklı hedef kitlelerine hitap etmesidir (Zengin ve Sancar, 2014:144).

Alternatif turizm; küçük ölçekli, düşük düzeyde yatırım gerektiren, yerel halkın yüksek derecede katılımını gerekli kılan, yerel halka olumsuz etkilerin en aza indirildiği, yerel halkın kararlara dahil edilmesini gerekli kılan nitelikler taşımaktadır (Triarchi ve Karamanis, 2017b). Yoksul yanlısı turizm, toplum temelli turizm, gönüllü turizm, eko turizm, sürdürülebilir turizm gibi toplumsal ve ekolojik dönüşümleri destekleyen farklı türleri de bünyesinde barındırmaktadır (Isaac, 2010:24). Alternatif turizm türleri, planlama ve geliştirme aşamasında doğal ve kültürel kaynaklara öncelik veren duyarlı bir yaklaşımla yapılmaktadır (Triarchi ve Karamanis, 2017b:36). Özetle, toplumsal ve çevresel duyarlılı̆̆a dayalı olması, doğaya dönüş ve doğay1 koruma bilinci gerektirmesi, yerel halkı turizm faaliyetlerine dâhil etmesi, yerel ürünlerin satışına ağırlık vermesi, yerel halka istihdam yaratması alternatif turizmin tipik özelliklerinden bazılarıdır.

\subsection{Bibliyometri ve İlgili Çalışmalar}

Bibliyometri terimi, ilk olarak Pritchard (1969) tarafından; kitaplara ve diğer iletişim araçlarına, matematiksel ve istatistiksel yöntemlerin uygulanması olarak tanımlanmıştır (Pritchard, 1969; Leung ve diğ., 2017:36). Başka bir tanımla, bibliyometri, akademik alanyazını istatistiki yöntemler kullanarak analiz etmedir (Ruhanen ve diğ., 2015:6). Özel ve Kozak'ın (2012:715) tanımıyla bibliyometri, belirli bir alanda yayımlanan çalışmaların nicel analizlerle incelendiği bir yöntemdir.

Bibliyometrik araştırmalarda, belgelerin ya da yayınların belirli özelliklerinin analiz edilmesiyle bilimsel iletişime yönelik bulgulara ulaşılır (Al ve Çoştur, 2007:144). Analiz; yayımlanmış çalışmaların gözlemlenmesi, değerlendirilmesi, tanımlanması için nicel bir yaklaşım kullanır. Bu yöntemler sistematik, şeffaf ve tekrarlanabilir bir inceleme süreci gerektirmekte ve bu durum yapılan incelemelerin kalitesini artırmaktadır (Zupic ve Cater, 2015:430). Aynı zamanda disiplinleri daha iyi tanımas1, tanıtmas1 ve araştırmacıların alanın durumu hakkında fikir sahibi olmasını mümkün kılmaktadır (Al ve Çoştur, 2007:157). $\mathrm{Bu}$ yöntemle, bir alanla ilgili yayımlanmış çalışmalar; yılı, konusu, yazar ve kaynakça sayısı, atıfları, yayımlandığı dergi, kullandığı araştırma yöntemi gibi kriterler bağlamında incelenir. Bununla birlikte; bu çalışmalarla bir konu hakkında yayın yapan en verimli yazarlar tespit edilebilirken, diğer yandan bunlar arasındaki etkileşim düzeyi belirlenebilmektedir (Ulu ve Akdağ, 2015:6).

Bir alanın bibliyometrik analizi yapılırken, öncelikle var olan veri tabanlarını değerlendirilerek, onların uygunluğu yani birinin veya diğerinin kullanımının sonuçlarını değerlendirmek esastır (Sanchez ve diğg., 2017:8). Bu yöntemler yeni olmasa da, kolayca erişilebilen veri tabanlarının çoğalmasıyla birlikte ilgi görmüştür (Zupic ve Cater, 2015:430). Gelişmelere bağlı olarak literatürde farklı alanlarda da s1klıkla kullanılmaya başlanmıştır.

Bir alanda geçmiş yıllarda yapılmış olan araştırmaların bulgularını sentezlemek, bir araştırma alanının gelişme göstermesi için elzem görünmektedir. Buna bağlı olarak, bibliyometrinin turizm araştırmalarındaki kullanımı da gün geçtikçe artış göstermektedir (Hall, 2011:16; Özel ve Kozak, 2012). Turizm araştırmalarında Palmer ve diğ., (2005) istatistiksel metodların kullanılmasını inceleyen ilk yazarlar olarak dikkat çekmektedir (Leung ve diğ., 2017:37). Daha sonra çalışmaların turizmin birçok alt dalına yayıldığı ve bu konularda da 
bibliyometri çalışmalarının yapıldığı görülmektedir. Turizm psikolojisi (Barrios ve diğ., 2008), sürdürülebilir turizm (Ruhanen ve diğ., 2015), şarap turizmi (Sanchez ve diğ., 2017), macera turizmi (Cheng ve diğ., 2018) gibi konularda yapılan bibliyometri çalışmaları bahsi geçen çalışmalardan bazılarıdır. Bununla birlikte turizm dergilerinin bibliyometrik yaklaşımla incelendiği çalışmaların da olduğu görülmektedir (Jimenez-Caballero ve Molina, 2017; Mulet-Forteza ve diğ., 2018; Strandberg ve diğ., 2018).

$\mathrm{Bu}$ gelişmelere paralel olarak; ulusal turizm yazınında da bibliyometrik yaklaşımın kullanıldığı birçok çalışma yayımlanmıştır. Örneğin, Güçlü Nergiz (2014) yaptığı çalışmada Türkiye'de 1990-2013 yılları arasında turizm alanında hazırlanan yüksek lisans ve doktora tezlerini; Aydın (2017) ise yiyecek içecek alanında yazılmış tezleri bibliyometrik bazı özellikler açısından incelemiştir. Çiçek ve Kozak (2012) Anatolia Turizm Araştırmaları Dergisi'nde yayımlanan dergilerin bibliyometrik bir profilini belirlemiş; Özel ve Kozak (2012), hakemli dergilerde yayımlanan ve turizm pazarlaması alanında yazılan makaleleri bibliyometrik özelliklere ve makalelerde yer alan atıflara göre incelemiştir. Yılmaz (2017a) 1978-2015 yılları arasında bahşş̧ konusunu ele alan makaleleri yıllara, dergilere, konulara, atıflara, veri toplama yöntemlerine, örneklem grubu gibi kriterlere göre incelemiştir. Zencir ve Kozak'ın (2012) çalışmasında Türkiye'de Sosyal Bilimler Enstitüleri tarafindan yayınlanan dergilerde yer alan turizm konulu makalelerin bibliyometrik profili çıkarılmıştır. Makaleler yayın yılı, konusu, dili, yazar sayısı, sayfa sayısı, kullanılan kaynak sayısı gibi kriterler temelinde değerlendirilmiştir. Yapılan çalışmalar incelendiğinde; bibliyometrik çalışmaların tezler ve seçilmiş dergilerde yayınlanan makaleler üzerinde yoğunlaştığı görülmektedir.

\section{YÖNTEM}

$\mathrm{Bu}$ çalışmada, alternatif turizm başlıklı makalelerin bibliyometrik bir yaklaşımla incelenmesi amaçlanmaktadır. Bu bağlamda YÖK Akademik veri tabanı kullanılmış; "alternatif turizm” kelimeleriyle arama yapılmış ve araştırmanın yapıldığı tarih itibarı ile 104 makale olduğu görülmüştür. Bazı makalelerin sistemde birkaç defa görüldüğü, bazılarının da erişime açık olmadığı gerekçesiyle ulaşılabilen 60 makale değerlendirmeye alınmıştır. Makaleler derinlemesine incelenmiş ve bulgular Microsoft Excel programında analiz edilmiştir. Makalelerin bibliyometrik profilinin belirlenebilmesi için yayımlandığı dergi, yıl, sayfa sayısı, yabancı ve yerli kaynak sayıları, makalelerin konulara göre dağılımı, yazar sayısı, yazarların çalıştıkları kurumlar ve bölümleri, anahtar kelime sayısı, kullanılan yöntemler incelenmiştir.

\section{BULGULAR}

Şekil 1'de alternatif turizm başlıklı makalelerin yayımlandığı yıllara ilişkin dağılım gösterilmektedir. İlgili çalışmaların en fazla (15 makale) 2017 yılında yayımlandığı görülmektedir. 2007-2008 yılları arasında artan makale sayısının 2015 yılına kadar belirgin düzeyde artmadığı ancak 2015 yılından sonra büyük artış olduğu görülmektedir. 2000, 2002, 2004, 2007 ve 2009 yıllarında 1 makale yayımlanmışken, bu sayı 2018 yılında 4 makaleye ulaşmışır.

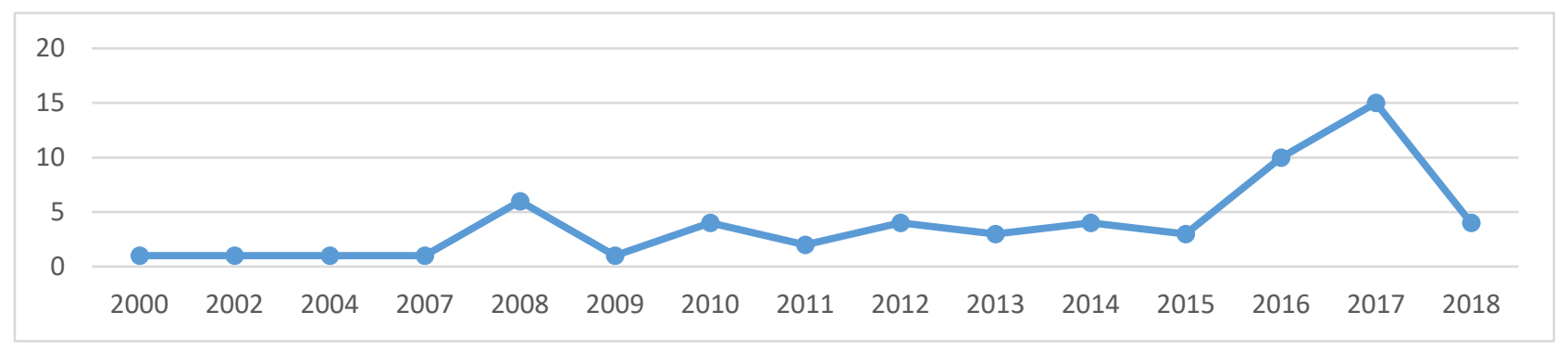

Şekil 1. Makalelerin Yıllara Göre Dağılımı

Alternatif turizm ile ilgili 60 makalenin hangi dergilerde yayımlandığ incelenmiş ve bu dağılım Şekil 2'de gösterilmiştir. Konu ile ilgili 51 farklı dergide makale yayımlanmıştır. Makalelerin en fazla yayımlandığı derginin 4 makale ile Atatürk Üniversitesi Sosyal Bilimler Enstitüsü Dergisi olduğu tespit edilmiştir. Ardından 3 makale ile Erzincan Üniversitesi Sosyal Bilimler Enstitüsü Dergisi bulunmaktadır. Üçüncü sırada ise 2 makale ile ASOS-The Journal of Academic Social Science (Uluslararas1 Sosyal Bilimler Dergisi), International Journal of Social and Economic Sciences, Mehmet Akif Ersoy Üniversitesi Sosyal Bilimler Enstitüsü Dergisi, Mustafa Kemal Üniversitesi Sosyal Bilimler Enstitüsü Dergisi, Social Sciences Studies Journal dergileri yer almaktadır. 


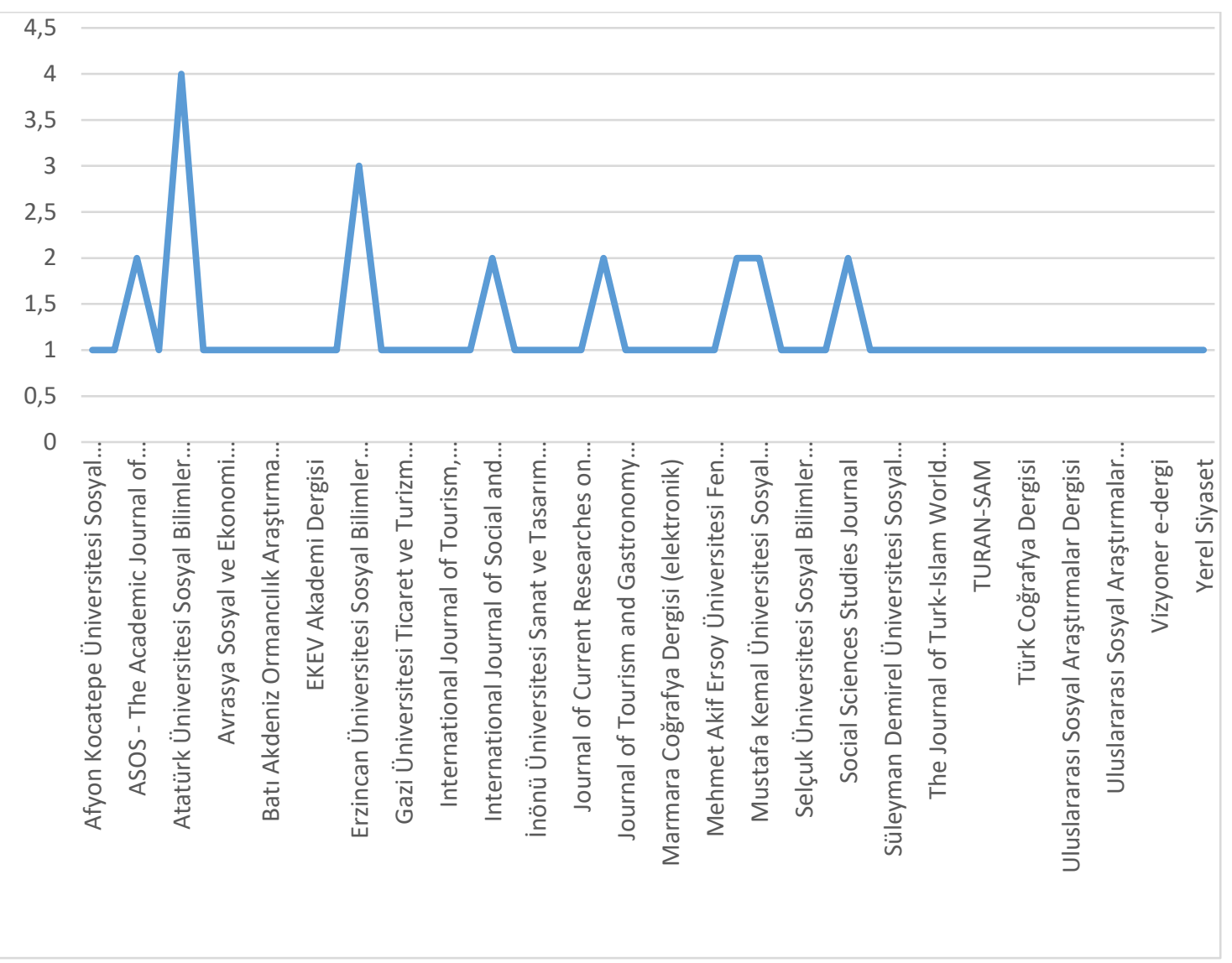

Şekil 2. Makalelerin Yayınlandığı Dergilere Göre Dağılımı

Șekil 3 alternatif turizm alanında yayımlanan makalelerdeki yazar sayılarını göstermektedir. 60 makalenin 33'ünün (\%55) iki yazarlı olduğu görülmektedir. Tek yazarlı 16 makale, üç yazarlı 9 makale, dört yazarlı 1 makale ve beş yazarlı 1 makale olduğu tespit edilmiştir.

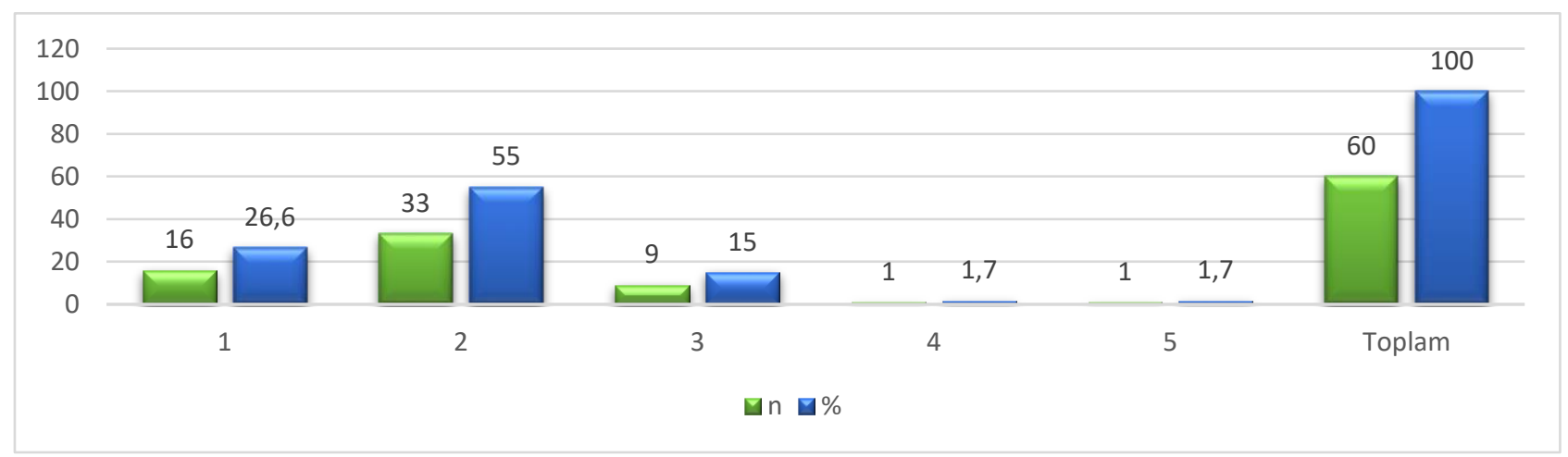

Şekil 3. Makalelerin Yazar Sayılarına Göre Dağılımı

Şekil 4'te makalelerin araştırma yaklaşımlarının yıllara göre dağılımı gösterilmektedir. Alternatif turizm alanında yapılan çalışmaların büyük bir bölümünün teorik çalışmalardan (40 makale) oluştuğu, en fazla teorik çalışmanın (9 makale) ise 2017 yılında yapıldı̆̆ı; daha sonra sırasıyla 2008 (6 makale), 2016 (6 makale) yıllarının izlediği görülmektedir. Diğer taraftan görgül çalışmaların 2010 yılından itibaren artmaya başladığı ve son yıllarda yavaş yavaş ivme kazandığı söylenebilir. 


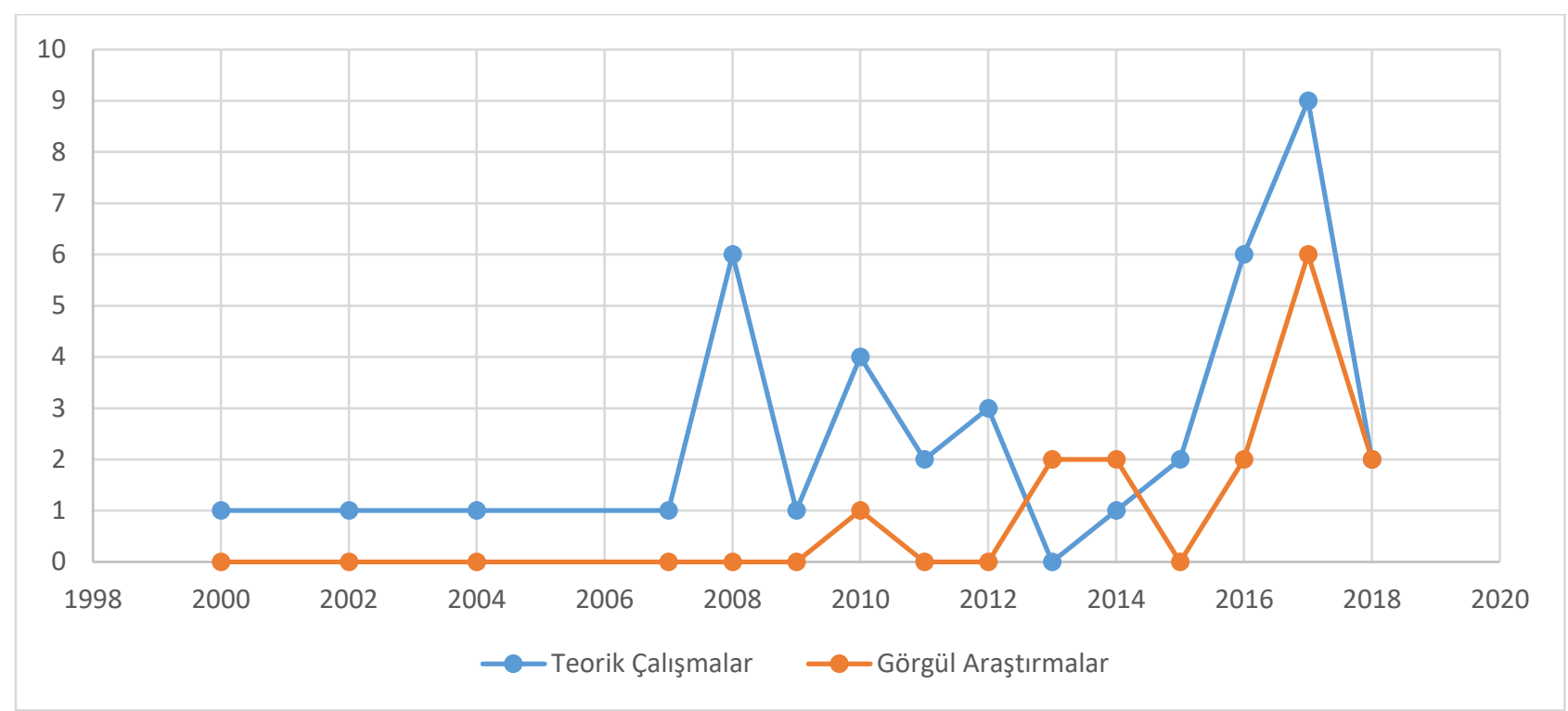

Şekil 4. Makalelerin Araştırmanın Yaklaşımlarının Yıllara Göre Dağılımı

Şekil 5'te yer alan makalelerin kaynakça sayılarının yerli ve yabancı ayrımı yapılarak yıllara göre dağılımı gösterilmiştir. Kaynakça sayılarının yıllara göre dağılımları; yerli kaynak kullanımının (1064) yabancı kaynak kullanımına göre (434) daha fazla olduğunu göstermektedir. Yıllara göre dağılıma bakıldığında; yerli kaynakça kullanımının en fazla olduğu yılların 2017 (283 makale), 2016 (166 makale) ve 2008 (159 makale) olduğu görülmektedir. Yabancı kaynak kullanımında ise, 2017 (102 makale) ve 2015 (90 makale) yıllarının öne çıtığı tespit edilmiştir.

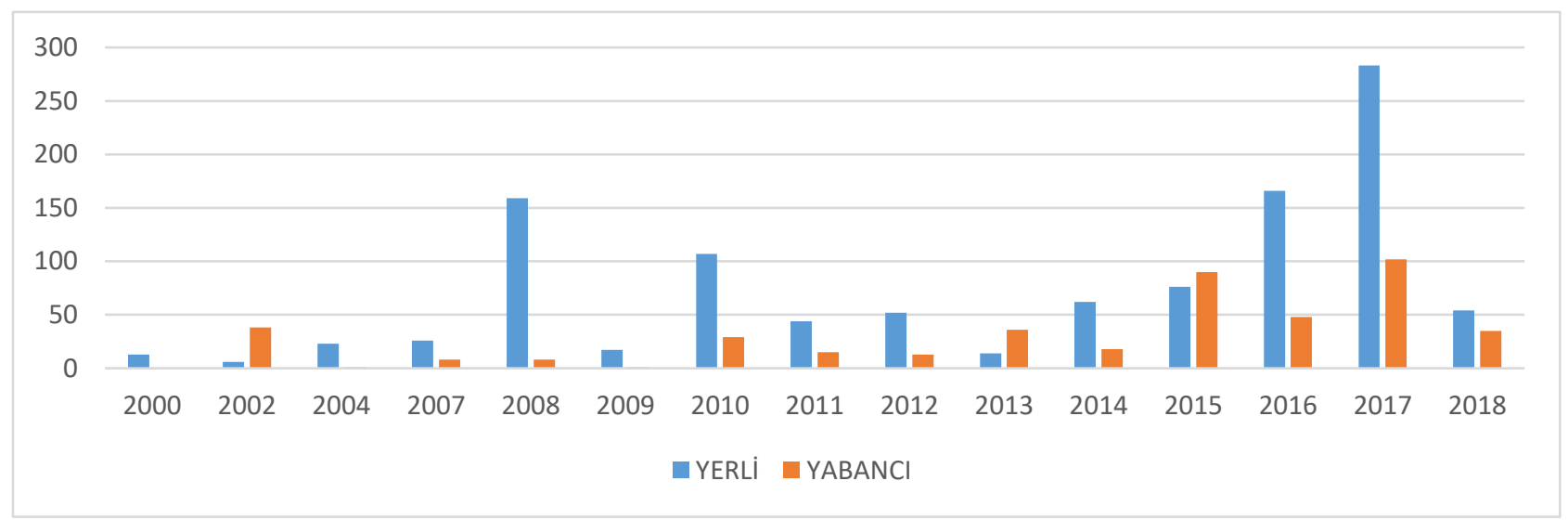

Şekil 5. Makalelerin Kaynakça Sayılarının Yıllara Göre Dağılımı

Şekil 6'da makalelerde kullanılan anahtar kelime sayıları görülmektedir. 26 makalede 4 adet anahtar kelime kullanıldığı tespit edilmiştir. 3 adet anahtar kelime kullanan 14 makale, 5 adet 11 makale, 1 adet 1 makale, hiç anahtar kelime kullanılmayan 2 adet makale bulunmaktadır.

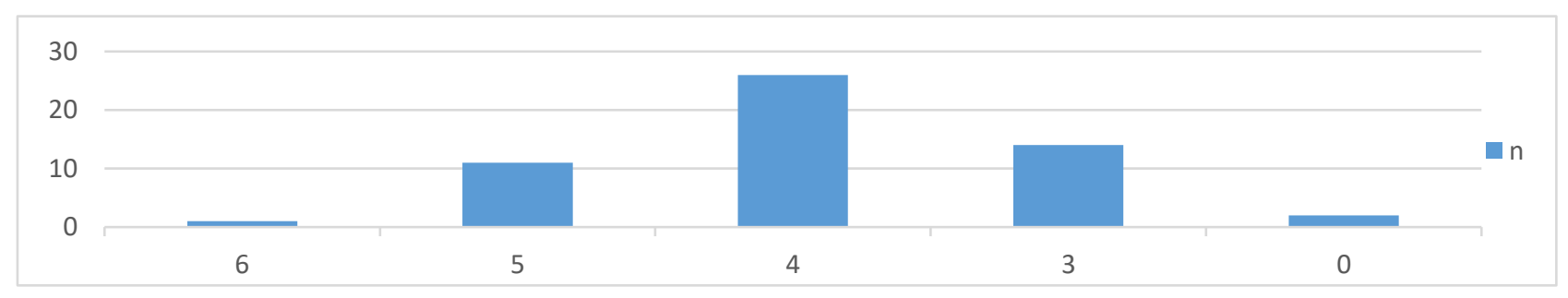

Şekil 6. Makalelerin Anahtar Kelime Sayısına Göre Dağılımı

Şekil 7'de makalelerde çalışılan konular ele alınmıştır. Konu başlıkları genel bir yaklaşımla değerlendirilmiş, benzer konu başlıkları bir başlık altında toplanmıştır. Alternatif turizm alanında en çok ele alınan konuların başında "alternatif turizm potansiyeli" başlığı dikkat çekmektedir. Bununla birlikte alternatif 
turizm ve kalkınma ilişkisi sıklıkla makalelere konu olmuştur. Alternatif turizm çeşitlerinin uygulanabilirliği ve bölge halkının turizme yönelik bakış açısı, tefekkür turizmi, futbol turizmi, atlı doğa yürüyüşü, hüzün turizmi, kış turizmi, yayla turizmi, kırsal turizm, dağ turizmi, mağara turizmi, gastronomi turizmi, av turizmi, kongre turizmi de incelenen diğer konu başlıklarındandır.

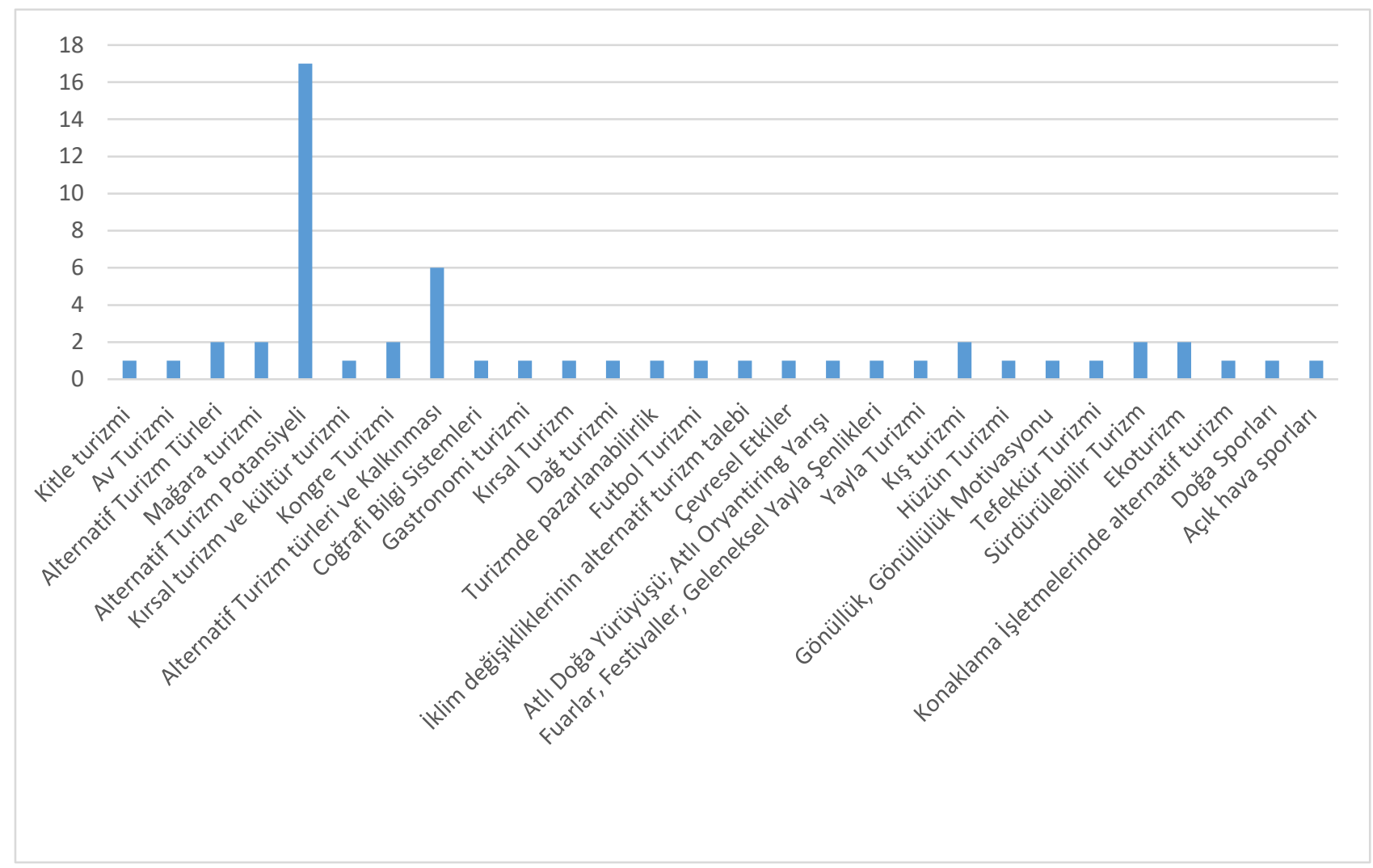

\section{Şekil 7. Makalelerin İçeriklerine İlişkin Bulgular}

Şekil 8'de makale yazarlarının unvanları incelenmiştir. İlgili çalışmaların en fazla Doktor Öğretim Üyesi unvanına sahip akademisyenler (48 kişi) tarafından yazıldığı görülmektedir. Doçent Doktor unvanına sahip akademisyenler (27 kişi) ise ikinci sırada yer almaktadır.

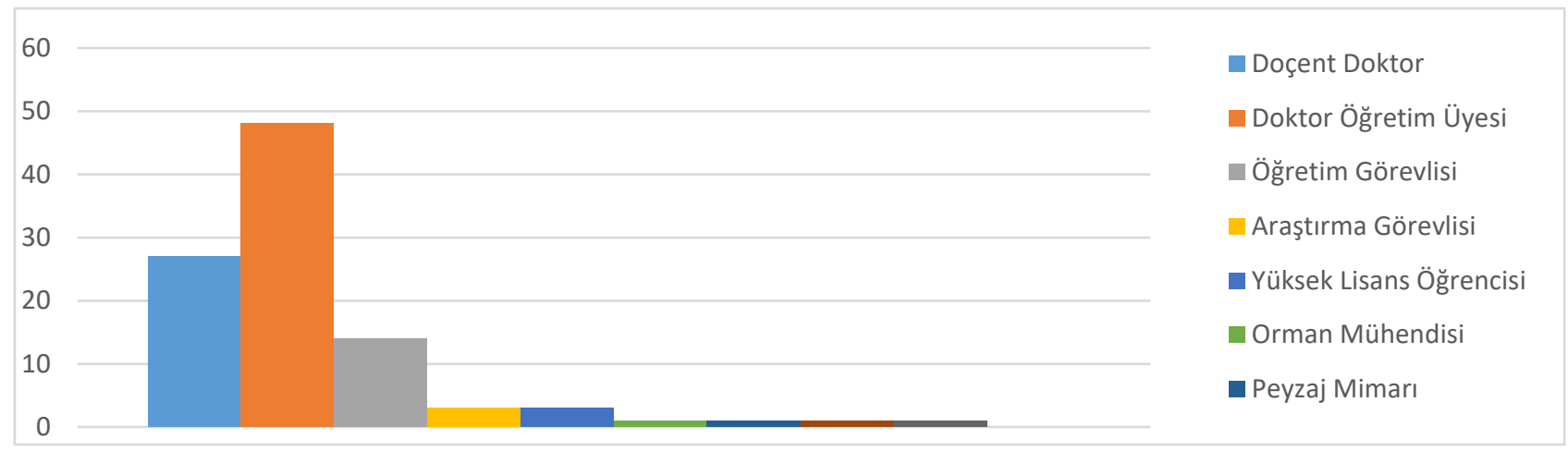

Şekil 8. Yazarların Unvanlarına Göre Dağılımı

Şekil 9'da makale yazarlarının çalıştıkları kurumlara göre dağılımı görülmektedir. Alternatif turizm alanında yapılan çalışmaların 36 farklı kurumda çalışan yazarlar tarafından yapıldığı saptanmıştır. En fazla çalışmanın Süleyman Demirel Üniversitesi'nde (14 makale), daha sonra sırasıyla Akdeniz Üniversitesi (9 makale) ve Muğla Sitkı Koçman Üniversitesi'nde (8 makale) görev yapan araştırmacılar tarafından yapıldığı görülmektedir. 


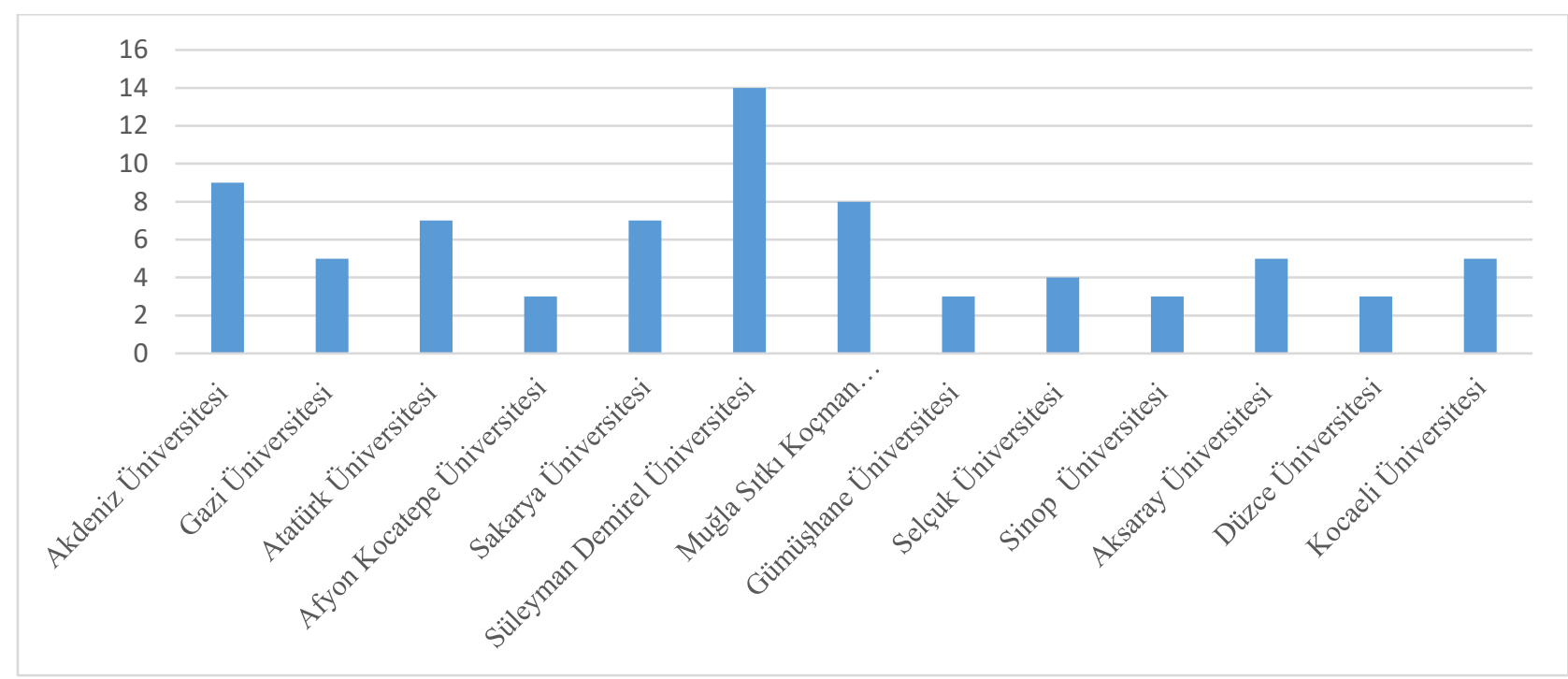

* Yazarların çalıştıkları kurumlarda 3 ve üzerinde olanlar dikkate alınmıştır.

\section{Şekil 9. Yazarların Çalıştığı Kurumlara Göre Dağılımı}

Şekil 10'da makale yazarlarının çalıştıkları bölümlerin dağılımı yer almaktadır. Bulgulara göre, en çok Turizm İşletmeciliği (32 makale), Turizm İşletmeciliği ve Otelcilik (14 makale) ve Coğrafya (11 makale) bölümünde çalışan akademisyenler tarafindan çalışma yapıldığı görülmektedir.

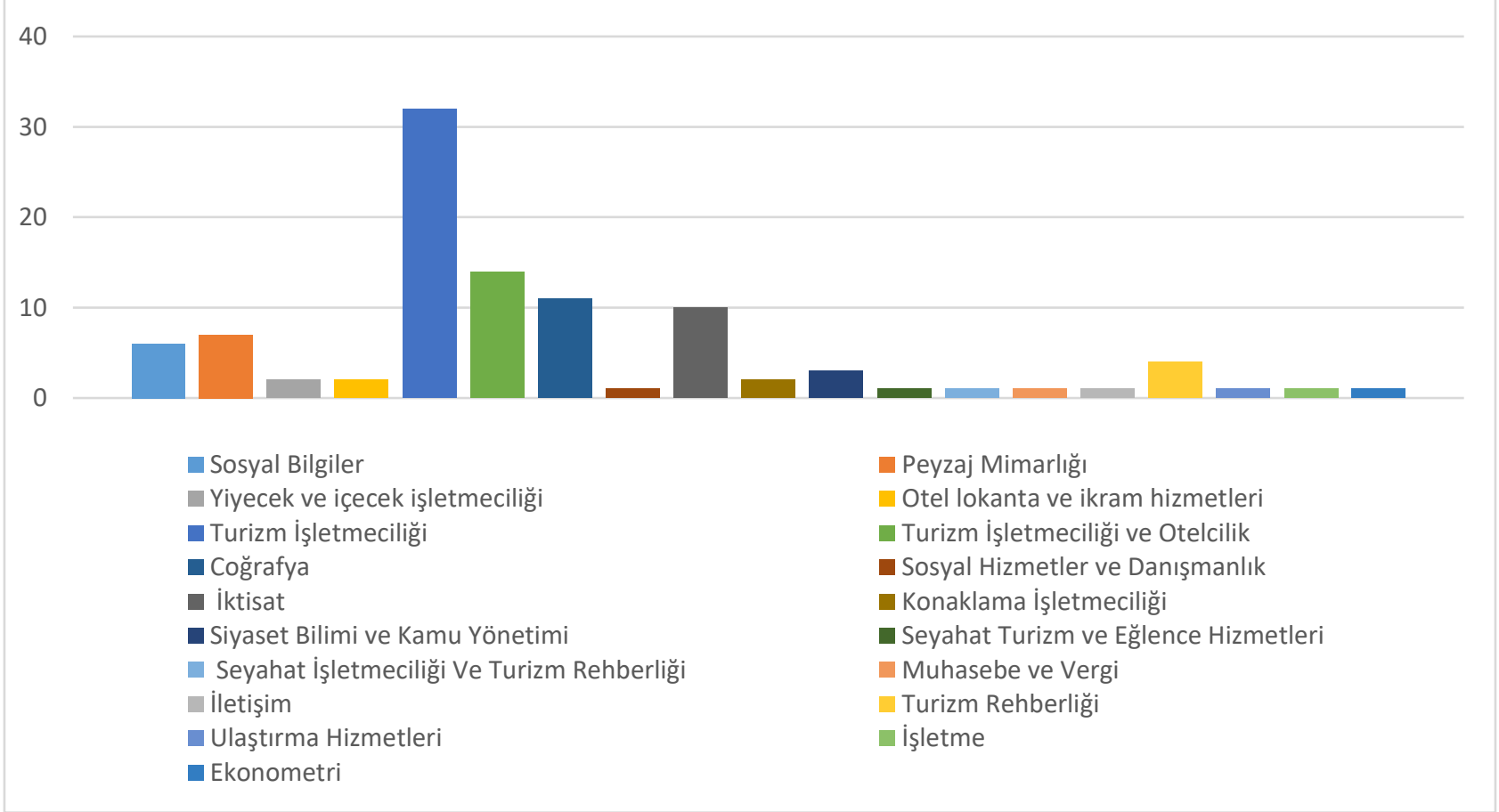

\section{Şekil 10. Yazarların Bölümlerine Göre Dağılımı}

\section{SONUÇ}

Çalışmada, YÖK Akademik veri tabanında yer alan alternatif turizm başlıklı makalelerin bibliyometrik özellikler açısından incelenmesi amaçlanmıştır. Erişim sağlanan 60 makale belirli parametreler çerçevesinde incelemeye alınmıştır. 2023 Türkiye Turizm Stratejisi'nde, alternatif turizmin geliştirilmesi için varış noktaları arasındaki ulaşım ağının iyileştirilmesi ve seyahat olanaklarının geliştirilmesine yönelik çalışmalar yapılmasının planlandığından bahsedilmektedir (www.kuzka.gov.tr). Alternatif turizmin geliştirilmesi hususundaki bu artan farkındalık, uygulama alanlarına paralel olarak literatürde de kendini göstermektedir. Nitekim araştırma bulguları da, alternatif turizm ile ilgili makalelerde 2015 y1lından itibaren artış olduğunu göstermektedir. Literatürdeki bibliyometrik araştırmalar incelendiğinde; artışın yalnızca makalelerde değil, tez 
ve bildirilerde de olduğu görülmektedir. Örneğin, Yılmaz (2017b) çalışmasında gastronomi alanında yapılan bildiri sayılarında giderek artış olduğunu belirtirken, Tayfun ve diğ., (2016:61-62) turizm alanında yazılan lisansüstü tezlerin 2007 yılından sonra artış gösterdiğini ortaya koymaktadır.

Çalışma bulguları makalelerin en çok Turizm İşletmeciliği bölümlerinde görev yapan yazarlar tarafindan yapıldığını göstersede, turizm alanı dışında, birçok farklı bölümde görev yapan araştırmacılarında konuya ilgi gösterdiğini ortaya koymaktadır. Bu durum turizmin disiplinler arası bir özellik göstermesiyle açıklanabilir. Ayrıca alternatif turizm; kabul gören, gelişme gösteren, farklı turizm türlerini içine alan ve bu sebeple birçok farklı disiplinin alanına giren bir konu olması sebebiyle de diğer alanlardaki araştırmacılar tarafından ilgi çekici bir konu olarak görülmektedir. Böylelikle farklı alanlardaki araştırmacılar da konuyla ilgili makale yazma eğiliminde olabilmekte, çeşitlilik meydana gelmektedir. Aynı durum yapılan başka çalışmaların konularına da yansımış görünmektedir. Örneğin Aydın (2017), yiyecek-içecek alanında yapılmış tezlerin konulara göre dağılımlarını incelemiş, dokuz farklı alanda konu ile ilgili tez yazıldığını tespit etmiştir. Yazara göre, yönetim organizasyon ve üretim yönetimi/pazarlama en sık tez yazılan alanlar olurken, gida mühendisliği, halk sağlı̆̆ ve mimarlık gibi alanlarda da azımsanmayacak sayıda tez üretilmektedir. Başka bir örnekle Güçlü Nergiz (2014), lisansüstü turizm tezlerini bibliyometrik yaklaşımla incelediği çalışmasında, Türkiye'de turizm konusunun farklı disiplinler tarafından da yoğun olarak çalışıldığını belirterek, özellikle coğrafya ve mimarlık konularına sıkça rastlandığını vurgulamaktadır.

Makale yazarlarının unvanlarına bakıldığında, makalelerin en çok Dr. Öğr. Üyesi unvanına sahip akademisyenler tarafından yazıldığı görülmektedir. Bu noktada bulgular, Erbaşı ve diğ. (2017) ve Şahin ve Acun'un (2015) çalışma bulgularıyla benzerlik göstermektedir. Bu durum Şahin ve Acun'un (2015) da belirttiği gibi, akademik yükselme kaygısının bu unvana sahip akademisyenler tarafından daha fazla hissedilmesi ve daha fazla yayın yapma çabasında olduklarıyla açıklanabilir.

Yerli ve yabancı kaynak kullanımına bakıldığında yerli kaynak kullanımının daha fazla olduğu ancak son yıllarda ise yabancı kaynak kullanımın ivme kazandığı görülmektedir. 2017 itibari ile yabancı kaynak kullanımının artmış olması yabancı dil konusundaki gelişmelere ve uluslararası yayınlara erişimin kolaylaşmasına bağlanabilir.

Yazar sayısı ve çok yazarlılık durumu ele alındığında, 60 makalenin toplam 110 yazar tarafından yazıldığı ve makalelerin çoğunun iki yazarlı olduğu dikkat çekmektedir. Çalışmanın bu bulgusu Sandıkçı ve Mutlu'nun (2019) çalışma bulgularıyla benzerlik göstermektedir. Alternatif turizm literatürüne katk1 sağlayan akademisyenlerin en fazla olduğu kurum Süleyman Demirel Üniversitesi olup ardından Akdeniz üniversitesi ve Muğla Sitkı Koçman Üniversitesi gelmektedir. Makalelerin içerikleri incelendiğinde en fazla belli bölgelerin alternatif turizm potansiyellerinin ve alternatif turizm kalkınmasının konu edinildiği görülmektedir. Söz konusu bulgular, konu edinilen bu bölgelerin/şehirlerin ağırlıklı olarak makale yazarlarının çalıştıkları kurumların bulundukları iller olduğunu göstermektedir. Araştırmacıların bulundukları illerin alternatif turizm potansiyellerini belirleme eğilimleri, araştırmacılar için zaman ve maliyet yükünü azaltma, bulundukları bölgelerin kalkınmasına fayda sağlama ve mevcut kaynaklara dikkat çekme gibi nedenlerle açıklanabilir.

Araştırmanın YÖK Akademik veri tabanında bulunan makalelerle sınırlı olması sebebiyle, farklı veri tabanlarında yer alan çalışmalar araştırma kapsamına alınamamıştır. Sonraki çalışmaların farklı veri tabanlarını da araştırmaya dâhil edilerek yapılması önerilebilir. Diğer taraftan araştırmanın yalnızca alternatif turizm başl1klı makaleler ile gerçekleştirilmesi bir sınırlılık olarak değerlendirilebilir. Kitap, tez ve bildiriler de dâhil edilerek; daha kapsamlı bibliyometrik çalışmalar yapılabilir. 


\section{KAYNAKÇA}

Akoğlan Kozak, Meryem, ve diğ., (2013). "Tarihsel Süreç İçinde Turizm Paradigması”, Anatolia Turizm Araştırmaları Dergisi, 24(1), s. 7-22.

Akoğlan Kozak, Meryem ve Sadık Bahçe, (2011) Özel İlgi Turizmi, 2. bs., Detay Yayıncılık, Ankara.

Al, Umut ve Recai, Çoştur (2007) “Türk Psikoloji Dergisi'nin Bibliyometrik Profili’, Türk Kütüphaneciliği 21(2), s. 142 163.

Ardıç Yetiş, Şule ve Zeynep, Çokal (2018) "Kış Turizmi Alanında Yayımlanan Makalelerin Bibliyometrik Profili", Journal of Recreation and Tourism Research, 5(1), 38-52.

Aydın, Bülent, (2017. "Yükseköğretim Kurulu Tez Merkezi’nde (YÖKTEZ) Yiyecek İçecek İşletmeciliği Alanında Kayıtlı Bulunan Tezlerin Bibliyometrik Analizi”, Disiplinlerarası Turizm Akademik Dergisi, 2(1), s. 23-38.

Barrios, Maite ve diğ., (2008) “A Bibliometric Study of Psychological Research on Tourism”, Scientometrics, 77(3), s. 453-467.

Baytok, Ahmet ve diğ., (2017) “Alternatif Turizm Mi Turizmde Çeşitlilik Mi? Kavramsal Bir Değerlendirme”, Erzincan Üniversitesi Sosyal Bilimler Enstitüsü Dergisi (Erzsosde), ÖS-IV, s. 1-14.

Bozok, Düriye, (2017) “Turizm Literatüründe Kırsal Turizmin Bibliyometrik Analizi” Journal of Human Sciences, 14(1), s. $187-202$.

Brohman, John (1996) "New Directions in Tourism for Third World Development”, Annals of Tourism Research, 23(1), s. $48-70$

Cheng, Mingming, (2018) "A Tri-Method Approach To A Review of Adventure Tourism Literature: Bibliometric Analysis, Content Analysis, and A Quantitative Systematic Literature Review", Journal of Hospitality \& Tourism Research, 42(6), s. 997-1020.

Christou, Loizos, (2012). "Is It Possible to Combine Mass Tourism with Alternative Forms of Tourism: The case of Spain, Greece, Slovenia and Croatia", Journal of Business Administration Online, 11(1), s. 1-8.

Cohen, Erik, (1987). "Alternative Tourism"- A Critique,” Tourism Recreation Research, 12(2), s. 13-18.

Çeken, Hüseyin, ve diğ., (2012) "Bir Alternatif Turizm Türü Olarak Kırsal Turizmin Gelişimini Etkileyen Faktörler ve Kırsal Turizmin Etkileri”, Uluslararası Sosyal ve Ekonomik Bilimler Dergisi, 2(2), s. 11-16.

Çetinkaya, Bozkurt, Özlem ve Ali Çetin, (2016) "Girişimcilik ve Kalkınma Dergisi'nin Bibliyometrik Analizi”, Girişimcilik ve Kalkınma Dergisi, 11(2), s. 229-263.

Çiçek, Dönüş ve Kozak, Nazmi, (2012) "Anatolia: Turizm Araştırmaları Dergisi'nde Yayımlanan Hakem Denetimli Makalelerin Bibliyometrik Profili”, Türk Kütüphaneciliği, 26(4), s. 734-756.

Duran, Erol ve Emrah Özkul, (2018) "Değişen Dünya Turizminde Yeni Alternatifler” (Ed.) Erol Duran ve Özlem Sertkaya Doğan, Türkiye Turizm Coğrafyası, Paradigma Akademi, Çanakkale.

Erbaşı, Ali, ve diğ. (2017). "Selçuk Üniversitesi Sosyal Bilimler Meslek Yüksekokulu Dergisi'nin Bibliyometrik Analizi”, Selçuk Üniversitesi Sosyal Bilimler Meslek Yüksekokulu Dergisi, 20(2), s. 206-214.

Erdoğan, Nazmiye (2003) "Kitle Turizmi, Alternatif Turizm ve Ekoturizmde Sürdürülebilirlik Üzerine Bir Değerlendirme", Türkiye'nin Alternatif Turizm Potansiyeli ve Güncel Sorunları Konferansı, 3-4 Mayıs, s. 133139.

Güçlü Nergiz, Hatice, (2014) “Türkiye'de Lisansüstü Turizm Tezlerinin Bibliyometrik Profili (1990-2013)”, VII. Lisansüstü Turizm Öğrencileri Araştırma Kongresi Nisan 04-05, Kuşadası, Aydın.

Güzeller, Cem Oktay ve Nuri Çeliker, (2017) "Geçmişten Günümüze Gastronomi Bilimi: Bibliyometrik Bir Analiz", Journal of Tourism and Gastonomy Studies, 5(2), s. 88-102.

Hall, Michael C., (2011) "Publish and Perish? Bibliometric Analysis, Journal Ranking and The Assessment of Research Quality in Tourism", Tourism Management, 32, s. 16-27.

Isaac, Rami Khalil, (2010) "Alternative Tourism: New Forms of Tourism in Bethlehem for The Palestinian Tourism Industry", Current Issues in Tourism, 13(1), s. 21-36.

Jimenez-Caballero, Jose Luis ve Silvia Polo, Molina, (2017) "A Bibliometric Analysis of The Presence of Finances in High-Impact Tourism Journals", Current Issues in Tourism, 20(3), s. 225-232.

Jovicic, Dobrica, (2016). "Cultural Tourism in The Context of Relations Between Mass and Alternative Tourism", Current Issues in Tourism, 19(6), 605-612.

Kılıç, Burhan ve Alper Kurnaz, (2010) “Alternatif Turizm ve Ürün Çeşitliliği Oluşturmada Ekolojik Çiftlikler: Pastoral Vadi Örneği”, İşletme Araştırmaları Dergisi, 2(4), s. 39-56.

Kısa Ovalı, Pınar, (2007) "Kitle Turizmi ve Ekolojik Turizmin Kavram, Mimari ve Çevresel Etkiler Bakımından Karşılaştırılması", Megaron Yıldız Teknik Üniversitesi Mimarlık Fakültesi E Dergisi, 2(2), s. 64-79.

Leung, Xi Y. ve di ̌̆., (2017) "Bibliometrics of Social Media Research: A Co-Citation and Co-Word Analysis", International Journal of Hospitality Management, 66, s. 35-45.

Macleod, D. V. L. (2005). Alternative tourism: a comparative analysis of meaning and impact. (123-139). İçinde Global Tourism, (Ed). William F. Theobald. Elsevier Science. Burlington,.

Mulet-Forteza, Carles, ve diğ., (2018) “Twenty Five Years of The Journal of Travel \& Tourism Marketing: A Bibliometric Ranking", Journal of Travel \& Tourism Marketing, 35(9), s. 1201-1221.

Özel, Çağıl Hale ve Nazmi Kozak, (2012) "Turizm Pazarlaması Alanının Bibliyometrik Profili (2000-2010) ve Bir Atıf Analizi Çalışması”, Türk Kütüphaneciliği, 26(4), s. 715-733. 
Pritchard, Alan, (1969) “Statistical Bibliography or Bibliometrics”, Journal of Documentation, 25(4), s. 348-349.

Roney, Akış, Sevgi, (2011) Turizm Bir Sistemin Analizi, 2. bs., Detay Yayıncılık, Ankara.

Ruhanen, Lisa ve diğ., (2015) "Trends and Patterns in Sustainable Tourism Research: A 25-Year Bibliometric Analysis", Journal of Sustainable Tourism, 23(4), s. 517-535.

Sanchez, Amador Duran ve diğ., (2017) "Bibliometric Analysis of Publications on Wine Tourism in The Databases Scopus and WoS", European Research on Management and Business Economics, 23, s. 8-15.

Sandıkçı, Mustafa ve Hülya Mutlu (2019) "Gastronomi Alanında Yayınlanan Makalelerin Bibliyometrik Profili (20132017)", Sosyal Bilimler Dergisi, 6(33), s. 32-42.

Strandberg, Carola ve diğ., (2018) "Tourism Research in the New Millennium: A Bibliometric Review of Literature in Tourism and Hospitality Research", Tourism and Hospitality Research, 18(3), s. 269-285.

Şahin, Seda ve Ayşen Acun (2015) "Turist Rehberliği Alanının Bibliyometrik Profili (Ulusal Turizm Kongreleri Bildirileri)", Balıkesir Üniversitesi Sosyal Bilimler Enstitüsü Dergisi, 18(34), s. 213-234.

Tayfun, Ahmet ve diğ., (2016) “Turizm Alanında Yazılan Lisansüstü Tezlere Yönelik Bibliyometrik Bir Analiz”, Gazi Üniversitesi Turizm Fakültesi Dergisi, 1, s. 50-69.

Triarchi Eirini ve Karamanis, Kostas, (2017a) "The Evolution of Alternative Forms of Tourism: A Theoretical Background", Business \& Entrepreneurship Journal, 6(1), s. 39-59.

Triarchi, Eirini ve Karamanis, Kostas, (2017b) “Alternative Tourism Development: A Theoretical Background", World Journal of Business and Management, 3(1), s. 35-54.

Ulu, Saniye ve Mustafa Akdağ, (2015) "Dergilerde Yayınlanan Hakem Denetimli Makalelerin Bibliyometrik Profili: Selçuk İletişim Örneği”, Selçuk İletişim, 9(1), s. 5-21.

Ulusan, Yeliz ve Orhan Batmaz, (2010) "Alternatif Turizm Çeşitlerinin Konya Turizmine Etkisi Üzerine Bir Araştırma”, Selçuk Üniversitesi Sosyal Bilimler Enstitüsü Dergisi, 23, s. 243-260.

Yılmaz, Gökhan (2017a) "Restoranlarda Bahşiș İle İlgili Yayınlanan Makalelerin Bibliyometrik Analizi”, Seyahat ve Otel İşletmeciliği Dergisi, 14(2), s. 65-79.

Yılmaz, Gökhan (2017b) "Ulusal Turizm Kongrelerinde Gastronomi ve Mutfak Sanatları Alanı İle İlgili Yayınlanan Bildiriler Üzerine Bir Araştırma", Turizm ve Araştırma Dergisi, 6(1), s. 23-38.

Zencir, Ebru ve Nazmi Kozak, (2012) "Sosyal Bilimler Enstitüsü Dergilerinde Yayımlanan Turizm Makalelerinin Bibliyometrik Profili”, VI. Lisansüstü Turizm Öğrencileri Kongresi Nisan 12-15, Antalya.

Zengin, Burhanettin ve Muhammet Fatih Sancar, (2014) "Alternatif Turizm Türlerinin Pazarlanabilirliği ve Seyahat Acentalarının Bakış Açıları: Şanlıurfa Örneği”, Bartın Üniversitesi İktisadi İdari Bilimler Dergisi, 5(10), s. 141 160.

Zupic, Ivan ve Tomaz Cater, (2015) “Bibliometric Methods in Management and Organization”, Organizational Research Methods, 18(3), s. 429-472.

https://www.kuzka.gov.tr/dosya/turizm_stratejisi_2023.pdf, Erişim Tarihi: 04.09.2019. 